\title{
PANDEMI COVID-19 DAN INOVASI PERPUSTAKAAN PERGURUAN TINGGI
}

\author{
Deri Hediana Priyadi \\ Program Studi Perpustakaan dan Sains Informasi Universitas Padjadjaran \\ E-mail: deri19001@unpad.ac.id \\ Sukaesih \\ Program Studi Perpustakaan dan Sains Informasi Universitas Padjadjaran \\ E-mail: sukaesih@unpad.ac.id \\ Evi Nursanti Rukmana \\ Program Studi Perpustakaan dan Sains Informasi Universitas Padjadjaran \\ E-mail: evi.nursanti.r@gmail.com \\ Samson CMS \\ Program Studi Perpustakaan dan Sains Informasi Universitas Padjadjaran \\ E-mail: samsoncms97@gmail.com
}

Received: 28-11-2020

Revised: 04-12-2020

Accepted: 12-12-2020

\begin{abstract}
The Covid-19 pandemic has had a huge impact on all elements of society, including information institutions such as libraries. Innovations made by information institutions such as libraries are mostly carried out on the development of library collections, library services, human resources. The purpose of this research is to look at innovations in college libraries in providing services to academicians due to covid-19. Digital libraries exist as an innovation in overcoming the problems of the Covid-19 pandemic. The research method uses descriptive qualitative methods, researchers conducted online interviews by sending emails to the email library. The data were obtained by interviewing the librarian of the college library. Innovations made in libraries involve human resources, library collections and services. Increasing human resources in the library by providing training on deficiencies in terms of services, turnover of librarians aims to provide officers with new experiences. Library collections experience sharing of resources where collaboration between libraries aims to fill the void in library collections in the library. Intership in libraries can be a movement in terms of library development, where intership is a place to accommodate young people who are rich in creative ideas and incoming invoices that make libraries more colorful.
\end{abstract}

Keyword: Covid-19 pandemic; digital library; collection development; library service innovation

\begin{abstract}
Pandemi covid-19 ini memberikan dampak yang begitu besar ke seluruh elemen masyarakat tidak terkecuali lembaga informasi seperti perpustakaan. Inovasi yang dilakukan oleh lembaga informasi seperti perpustakaan banyak dilakukan terhadap pengembangan koleksi pustaka, layanan perpustakaan, sumber daya manusia. Tujuan dari penelitian ini adalah untuk mengetahui inovasi di perpustakaan perguruan tinggi dalam memberikan layanan kepada sivitas akademika dampak covid-19. Perpustakaan digital hadir sebagai inovasi dalam mengatasi permasalahan dipandemi covid-19. Metode penelitian menggunakan metode kualitatif deskriptif, dimana peneliti melakukan wawancara secara online dengan mengirimkan e-mail kepada e-mail perpustakaan. Data diperoleh
\end{abstract}


Published by Program Studi Perpustakaan dan Ilmu Informasi

FBS Universitas Negeri Padang, Indonesia

dengan melakukan wawancara terhadap pustakawan perpustakaan perguruan tinggi. Inovasi dilakukan kepada perpustakaan melibatkan sumberdaya manusia, koleksi dan layanan perpustakaan. Meningkatkan sumber daya manusia dalam perpustakaan dengan memberikan pelatihan terhadap kekuranganya dalam hal layanan, pergantian petugas perpustakaan bertujuan utnuk memberikan petugas lain pengalaman baru. Koleksi perpustakaan mengalami Resource sharing dimana kerja sama antar perpustakaan bertujuan mengisi kekosongan koleksi pustaka diperpustakaan. Adanya intership diperpustakaan dapat sebagai gerakan dalam hal perkembangan perpustakaan, dimana intership sebagai wadah untuk menanmpung anak muda yang kaya akan ide kreatif dan invoasi masuk yang membuat perpustakaan semakin berwarna.

Kata Kunci: covid-19; perpustakaan digital; perkembangan koleksi; inovasi layanan perpustakaan.

\section{PENDAHULUAN}

Perkembangan zaman yang begitu pesat tidak lupa informasi pun ikut berkembang pesat, dimana dahulu untuk mendapatkan informasi medianya pun masih terbatas hanya koran, tv, radio, dan lain-lain. Sekarang informasi melimpah ruah dan tidak terbendung arus informasinya, oleh karena itu masyarakat sekarang harus bisa membedakan informasinya yang valid dan baik buat kita dan mana yang tidak baik buat kita. Apalagi saat ini dunia sedang terjadi pandemic Covid-19 dimana penyakit ini terjadi oleh virus bernama SARS-CoV-2. Akibat virus $S A R S-C o V-2$ ini kita diwajibkan untuk bekerja, belajar dan melakukan aktivitas dirumah yang dimana sebelumnya kita melakukannya di luar rumah. Di masa seperti saat ini, para masyarakat akan memfokuskan dirinya pada media berita melalui televisi, media sosial maupun media online lainnya. Masyarakat juga akan menggunakan waktunya untuk berselancar informasi di internet dan media komunikasi seperti Line, WhatsApp, Telegram, Facebook, Twitter, dan Instagram untuk memperoleh informasi terbaru/ up-to-date terkait dengan Covid-19 ( Suharso, Arifiyana, \& Wasdiana, 2020). Terlebih lagi di lembaga informasi seperti perpustakaan, harus bisa memberikan informasi yang valid untuk masyarakat. Lembaga perpustakaan disaat pandemi, ini pun harus berinovasi dengan melakukan perpustakaan digital.

Perpustakaan berasal dari bahasa latin yaitu libre atau liber yang artinya buku. Perpustakaan dalam bahasa belanda disebut bibliotheca,Jerman disebut bibliothek,Perancis disebut bibliotheque.Spanyol disebut bibliotheca dan Portugis disebut bibliotheca. Semua istilah itu berasal dari yunani yang artinya buku. Orang yang terlibat dalam dunia perpustakaan biasa di sebut pustakawan. Pustakawan dalam bahasa inggris disebut librarianship. Kepustakawanan mencakup dalam semua hal seperti hal pengadaan,penggunaan serta pendayagunaan buku. Perpustakaan terbagi menjadi empat jenis yaitu perpustakaan umum, perpustakaan sekolah, perpustakaan perguruan tinggi dan perpustakaan khusus. Keempat jenis perpustakaan memiliki empat fungsi dasar perpustakaan yaitu fungsi informatif, edukatif, kultural dan rekreasi. Fungsi informatif di perpustakaan menunjukkan bahwa perpustakaan didirikan untuk menyediakan suatu informasi yang dibutuhkan oleh pengguna perpustakaan ataupun masyarakat. Kedua yaitu fungsi edukatif perpustakaan dibangun untuk menyediakan pendidikan sepanjang hayat bagi masyarakat biasanya koleksi pustakanya terdapat bermacam-macam ilmu mau yang murni, terapan dan praktis disegala bidang. Ketiga fungsi kultural 
yaitu perpustakaan berfungsi melestarikan kebudayaan dalam berbagai literatur untuk dibaca oleh masyarakat. Keempat fungsi rekreatif menawarkan bacaaan yang mudah dipahami dan isinya tidak terlalu sulit bahasanya, biasanya jenis bacaanya yg sering ada di perpustakaan umum seperti novel, majalah dan komik.

Perkembangan zaman membuat teknologi informasi masuk kedalam perpustakaan, oleh karena itu perpustakaan konvesional berubah menjadi perpustakaan digital. Perpustakaan digital atau library digital merupakan perpustakaan yang menggunakan teknologi terbaru dalam pelayananya, perpustakaan digital sudah dimiliki di seluruh dunia termasuk Indonesia. IFLA (The International Federation of Library Associations and Institutions) (2018) mendefinisikan perpustakaan digital sebagai berikut: "a digital library is an online collection of digital objects, of assured quality, that are created or collected and managed according to internationally accepted principles for collection development and made accessible in a coherent and sustainable manner, supported by services necessary to allow users to retrieve and exploit the resources." yang mengandung arti bahwa perpustakaan digital merupakan perpustakaan yang memiliki koleksi online yang berisi objek digital dengan yang berkualitas, dikembangkan dan dikelola sesuai dengan prinsip secara internasional. Selain itu, koleksi yang ada dapat diakses secara berkelanjutan atau dibuka secara terus-menerus yang didukung oleh layanan-layanan yang diperlukan oleh pengguna ketika menggunakan/ membutuhkan sumber informasi. Perpustakaan digital di Indonesia di pelopori oleh Perpustakaan Institut
Teknologi Bandung pada tahun 1980an. Sekarang hampir semua universitas di Indonesia memiliki perpustakaan digital, akan tetapi ada beberapa yang tidak memilikinya dikarenakan untuk membuat perpustakaan digital harus membutuhkan sarana dan prasarana yang memadai.

Perpustakaan digital hampir sama dengan perpustakaan konvesional, yang membedakanya di jenis koleksi perpustakaan, tempat dan jenis layanannya. Pandemi sekarang ini perpustakaan digital, di nilai cocok untuk memberikan layanan informasi kepada masyarakat luas. Menurut Gatot Subrata (2009) beberapa keunggulan perpustakaan digital diantaranya adalah sebagai berikut: Long distance service, artinya dengan perpustakaan digital, pengguna bisa menikmati layanan sepuasnya, kapanpun dan dimanapun. Akses yang mudah. Akses pepustakaan digital lebih mudah dibanding dengan perpustakaan konvensional, karena pengguna tidak perlu dipusingkan dengan mencari di katalog dengan waktu yang lama. Murah (cost efective). Perpustakan digital tidak memerlukan banyak biaya. Mendigitalkan koleksi perpustakaan lebih murah dibandingkan dengan membeli buku. Mencegah duplikasi dan plagiat. Perpustakaan digital lebih "aman", sehingga tidak akan mudah untuh diplagiat. Bila penyimpanan koleksi perpustakaan menggunakan format PDF, koleksi perpustakaan hanya bisa dibaca oleh pengguna, tanpa bisa mengeditnya. Publikasi karya secara global. Dengan adanya perpustakaan digital, karya-karya dapat dipublikasikan secara global ke seluruh dunia dengan bantuan internet.

Adanya perpustakaan digital ini, masyarakat dapat mengakses perpustakaan dari mana saja, kapan saja dan jam berapa 
saja tidak seperti perpustakaan konvesional lainya. Apalagi sedang ada pandemi covid-19 ini dengan adanya perpustakaan digital, dapat membantu masyarakat untuk mencari informasi di perpustakaan. Perpustakaan digital tidak harus membutuhkan ruangan untuk beroperasi, tinggal sarana server dan sumberdaya manusianya untuk menjalankan perpustakaan digital dan koleksi-koleksi digital. Perpustakaan konvesional dan digital sama-sama memiliki petugas, petugas tersebut biasa kita sebut sebagai pustakawan. Definisi pustakawan sebagaimana pada kode edtik pustakawan dalam (Wahyuni, 2015) ialah seseorang yang menjalankan kegiatan perpustakaan dengan memberikan pelayanan pada masyarakat sesuai akan tugas lembaga induknya dengan berdasar padaa ilmu yang dimiliki melalui pendidikan. Pustakawan ini juga selain memberikan pelayanan, tetap harus memberikan kontribusi terhadap kepada perpustakaan dengan memberikan ide-ide inovasi supaya perpustakaan tidak tertinggal. Terdapat petugas perpustakaan atau pustakawan bertujuan untuk mengelola perpustakaan dengan baik dan benar, pustakawan itu sendiri memiliki background dari sarjana Sains Informasi dan Perpustakaan. Pustakawan harus memiliki karakteristik profesionalismenya diantara lain, seperti memiliki ilmu pengetahuan, keterampilan, keahlian dalam bidang sains informasi dan perpustakaan.

Perpustakaan mempunyai dua layanan untuk membantu masyarakat untuk mencari informasi. Layanan di lembaga informasi terutama perpustakaan terdapat dua macam yaitu layanan referensi dan layanan sirkulasi akan tetapi kali ini kita akan membahas layanan referensi. Layanan Referensi ini merupakan layanan yang sangat dibutuhkan oleh suatu lembaga informasi yaitu perpustakaan. Layanan tersebut merupakan tolak ukur bagus tidaknya suatu perpustakaan dalam menangani pencarian informasi. Layanan referensi berasal dari kata reference dimana dalam Bahasa Inggris to refer yang artinya menunjuk. Sedangkan dalam Kamus Besar Bahasa Indoesia adalah sumber, acuan, rujukan atau petunjuk.

Layanan referensi menurut Summerhill memberi definisi sederhana bahwa layanan referensi adalah fasilitas yang menghubungkan pencari informasi dengan informasi yang mereka butuhkan. Sedangkan menurut The Reference and User Services Association (RUSA) memberikan definisi bahwa layanan referensi adalah layanan informasi di perpustakaan yang terdiri dari berbagai macam bentuk kegiatan layanan, termasuk bimbingan personal, direktori, pemberian informasi yang dipilih dari suatu sumber referensi, layanan bimbingan pembaca (readers advisory service), dan akses untuk informasi digitial untuk pemustaka. Layanan referensi merupakan suatu layanan yang tedapat ruangan di lembaga informasi terutama perpustakaan, yang berfungsi dan bertugas untuk membantu pengguna perpustakaan dalam hal mencari informasi, meminjam buku dan lainnya.

Dalam layanan referensi terdapat petugas untuk membantu para pengguna perpustakaan itu sendiri, dimana seiring perkembangan zaman ini layanan referensi mulai mengalami sedikit ditinggalkan akan tetapi memiliki peran yang penting dalam perpustakaan. Selain layanan referensi terdapat juga layanan sirkulasi di perpustakaan. Layanan sirkulasi 
merupakan suatau kegiatan layanan peminjaman dan pengembalian koleksi di perpustakaan yang sudah terprogram didalam perpustakaan. Kegiatan layanan sirkulasi hampir mirip dengan layanan referensi seperti menyediakan bahan pustaka, mengadakan pengawasan koleksi akan tetapi layanan sirkulasi tidak mencatat pertanyaan-pertanyaan yang diajukan oleh pengguna perpustakaan. Dalam melakukan layanan referensi petugas perpustakaan harus mengetahui jenis-jenis koleksi yang ada diperpustakaan itu sendiri ataupun yang lagi dicari. Layanan yang mengurusi tentang koleksi, jenis dan perkembagan yaitu pengembangan koleksi.

Definisi pengembangan koleksi (collection development) sebuah proses mengidentifikasi kekuatan dan kelemahan koleksi perpustakaan dalam memenuhi kebutuhan pengguna serta berupaya mengatasi kelemahan tersebut (Laksmi, 2013). Definisi pengembangan koleksi lainnya adalah Pengembangan koleksi adalah proses memenuhi kebutuhan informasi masyarakat secara tepat waktu dan tepat guna dengan memanfaatkan sumber daya informasi yang dikelola oleh perpustakaan atau yang dikelola oleh perpustakaan lain (Evans \& Saponaro, 2005: 7). Namun demikian, beberapa pakar membedakan kedua istilah tersebut (Pendit, 2009: 70). Istilah manajemen koleksi cenderung merujuk pada tata kelola dalam melaksanakan akuisisi secara sistematis yang mencakup perencanaan, pengaturan komposisi koleksi, penganggaran, evaluasi, serta pemanfaatan koleksi dalam satu periode waktu dan dalam memenuhi kebutuhan lembaga (Clayton \& Gorman, 2001: 16). Pengembangan koleksi dimaknai sebagai kegiatan yang lebih berfokus pada konten koleksi dalam kaitannya dengan kebutuhan pengguna. Koleksi perpustakaan pun beragam, tergantung jenis perpustakaanya itu sendiri.

Mengindentifikasi suatu koleksi diperpustakaan merupakan, langkah yang dilakukan oleh petugas perpustakaan yang berguna untuk memilah suatu koleksi pustaka mana yang masih bisa digunakan dan tidak. Selain itu dengan diadakanya pengembangan koleksi (collection development) dana pembelian koleksi pustaka baru tidak membengkak, dikarenakan sebelumnya kita sudah menganalisis kebutuhan koleksi yang dibutuhkan oleh pengguna perpustakaan. Dahulu koleksi perpustakaan hanyalah sebuah fisik seperti buku, jurnal, cd-room tetapi seiring perkembangan zaman koleksi perpustakaan pun beragam mulai dari buku elektronik, film, music. Kemajuan teknologi informasi membuat perkembangan percetakan terhadap media cetak berkembang pesat, dikarenakan mudah didapat dan harganya tidak semahal dulu.

Percetakan sekarang pun ada yang digital, dimana membuat koleksi putaka kita menjadi digital yang bisa di akses dimana saja dengan bantuan internet. Perkembangan koleksi sejalan dengan perkembangan dimasyarakat, dimana dahulu masyarakat agraris menjadi masyarakat industri. Masyarakat industri merupakan masyarakat yang menciptakan suatu jasa dan produk, berbeda dengan masyarakat agraris yang dimana masyarakat bergantung kepada alam. Masyarakat industri ini tergantung dengan teknologi informasi untuk menciptakan suatu karya, oleh karena itu koleksi yang dibutuhkan pun beragam. Dalam melakukan proses pengembangan koleksi 
pustakawan melakukan sembilan kegiatan yang dimulai dari kegiatan mengidentifikasi, menyeleksi, pengadaan, pengorganisasian, pengolahan, penyimpanan, menginterpretasi, pemanfaatan, dan penyebaran. Seiring dengan perkembangan zaman, jenis koleksi perpustakaan pun bertambah yang dahulu karya non cetak, cetak dan mikro sekarang ada sumber daya elektronik. Sumber daya elektronik ini terdiri dari delapan jenis sumber yaitu jurnal elektronik, buku elektronik (e-books), pangkalan data naskah lengkap (aggregated databases), pangkalan data indeks dan abstrak, pangkalan data referensi, pangakalan data statistik dan angka, gambar elektronik, sumber daya audio / visual elektronik.

Jurnal elektronik merupakan jurnal ilmiah yang dapat diakses melalui dokumen elektronik melalui sarana komputer yang berbentuk PDF (portable documen format) dan bentuk lainya tentunya untuk mengakses jurnal ini butuhkan koneksi internet. Buku elektronikl (e-books) merupakan buku cetak yang fisiknya berubah menjadi digital. Format dari buku ini biasanya epub,pdf,lit dan lain-lain, biasanya dapat di unduh di googleplaybooks,amazon prime book,ebrary, ebscohost books, wiley ebooks dan springer e-books. Indonesia sendiri melalui Kementerian Pendidikan Nasional menerbitkan layanan buku sekolah elektronik. Buku sekolah elekronik ini merupakan buku legal yang berbasis legal tersedia dari tingakatan sekolah dasar sampai atas. Pangkalan data indeks dan abstrak merupakan sumber informasi elektronik yang berisikan berbagai jenis informasi secara elektronik. Contohnya model sumber daya elektronmik seperti SCOPUS dan Proquest
Abstract. Pangkatan data referensi merupakan sumber daya elektronik pangakalan data referensi dalam memberikan suatu informasi yang terdapat dalam biografi, kamus, direktori, ensiklopedia dan lain-lainya. Contohnya pangakalan data referensi adalah BRITANNICA ONLINE. Sumber daya audio / visual merupakan sumber yang menyediakan data dalam bentuk audiovisual seperti film, video-klip, musik, dokumenter dan lain-lain, Contohnya seperti Youtube, Itunes, Spotify, Netflix, IDMB.

Bentuk mikro dalam jenis koleksi merupakan bahan pustaka yang menggunakan media khusus dan cara bacanya harus menggunakan alat khusus. Alat untuk membaca jenis mikro yaitu microreader. Bahan pustaka ini meliputi informasi seperti bahan cetak, majalah, surat kabar, dan lain-lainya. Terdapat tiga jenis bentuk mikro dalam koleksi yaitu mikrofilm, mikrofis dan micropaque. Mikrofilm merupakan bentuk mikro dalam gulungan film, jenis gulungan ini terdapat tiga jenis yaitu $8 \mathrm{~mm}, 16 \mathrm{~mm}$, dan $35 \mathrm{~mm}$. Mikrofilm ini bisa dibaca melalui proyektor. Kedua yaitu Mikrofis dalam bentuk mikro merupakan lembaran film dengan ukuran $105 \mathrm{~mm}$ dan $148 \mathrm{~mm}$ dan standarnya $75 \mathrm{~mm}$ x $125 \mathrm{~mm}$. Ketiga micropaque merupakan bentuk mikro ketika informasi dicetak kedalam kertas yang tidak tembus cahaya serta ukurannya mikrofis.

Peneliti mengakat permasalahan yang sedang dihadapi sekarang ini yaitu, pandemi covid-19 dimana semua sektor masyarakat terkena imbasnya. Oleh karena itu dari permasalah tersebut maka saya mengangkat rumusan masalah terhadap layanan informasi yaitu perpustakaan. 
Terdampak pandemi covid-19 perpustakaan pun dituntut untuk bekerja lebih estrak, dimana harus menyediakan informasi dari biasanya. Maka tulisan ini mengangkat rumusan masalah sebagai berikut bagaimana meningkatkan kualitas petugas layanan perpustakaan?, bagaimana sumber daya manusia dalam menghadapi pengembangan koleksi di era pandemic covid-19?, dan inovasi apa saja disaat pandemic covid-19 terhadap layanan perpustakaan

\section{METODE PENELITIAN}

Dalam penelitian ini peneliti menggunakan metode kualitatif deskriptif, dimana peneliti melakukan wawancara secara online dengan mengirimkan e-mail yang berisi beberapa pertanyaan kepada perpustakaan perguruan tinggi dikarenakan pandemi Covid-19. Metode kualitatif deskriptif menurut Nazir dalam buku Metode Penelitian merupakan suatu metode untuk meneliti status masyarakat, suatu situasi, sistem pemikiran dan peristiwa pada zaman sekarang. Sedangkan penelitian kualitatif merupakan penelitian riset yang mengarah kedalam pemakaian metode analisis dalam prosesnya. Dalam Moleong karya Taylor dan Bogdan penelitian kualitatif merupakan langkah peneliti berupa hasil informasi deskriptif verbal tulis maupun lisan. Perpustakaan yang peneliti melakukan wawancara untuk mendapatkan data layanan di perpustakaan merupakan perpustakaan perguruan tinggi di Kota Bandung yaitu Universitas Padjajaran. Proses pelaksanaan wawancara dengan mengirimkan e-mail dilakukan pada hari Jumat tanggal 20 bulan november 2020 . Narasumber wawancara adalah seorang pustakawan di perpustakaan Universitas Padjajaran. Penelitian ini bertujuan supaya kita mengetahui bagaimana caranya lembaga informasi terutama perpustakaan , bisa berinovasi ditengah pandemi covid19. Wawancara dengan mengajukan lima buah pertanyaan kepada e-mail perpustakaan.

\section{HASIL DAN PEMBAHASAN}

Hakikatnya layanan perpustakaan tempat penyediaan akan segala bentuk bahan pustaka dengan akurat dan tepat sesuai dengan kebutuhan pemustaka dalam sarana penelusuran informasi, maka dari itu penyediaan fasilitas sarana temu balik pelu dimiliki perpustakaan (Rahayu, 2014). Jangkauan perpustakaan tidak hanya berkutat pada masyarakat penaungnya seperti perpustakaan perguruan tinggi hanya untuk mahasiswa, atau perpustakaan khusus untuk lembaga yang menaungi. Pada dasarnya hal tersebut hanya bersifat administratif agar memudahkan pengelolaan perpustakaan, namun tetap masyarakat lain dapat mengaskses perpustakaan tersebut. Layanan perputaskaan mempunyai dua layanan untuk membantu masyarakat untuk mencari informasi. Layanan di lembaga informasi terutama perpustakaan terdapat dua macam yaitu layanan referensi dan layanan sirkulasi akan tetapi kali ini kita akan membahas layanan referensi. Apalagi dimasa pandemi Covid19 masyarakat membutuhkan suatu informasi, koleksi pustaka walaupun layanan tidak bisa dilakukan secara konvesional melainkan digital. Layanan referensi merupakan layanan penting dalam perpustakaan, dimana layanan ini menjadi tolak ukur suatu perpustakaan oleh karena itu perpustakaan harus mengasih wawasan kepada semua yang bekerja di lingkungan perpustakaan tidak terkecuali petugas layanan referensi ini. 
Petugas layanan ini bertugas untuk membantu para pengguna perpustakaan untuk mendapatkan informasi yang tepat dan valid. Petugas ini setiap detik akan berhadapan dengan berbagai jenis sifat manusia, oleh karena itu petugas ini harus memiliki beberapa syarat supaya bisa ditempatkan di layanan referensi.

Pustakawan harus mempunyai pengetahuan yang luas, dikarenakan setiap pengguna perpustakaan akan menanyakan suatu informasi yang mereka cari. Apabila pustakawan mempunyai pengetahuan yang luas mereka bisa menjawabnya dan memberikan nilai positif bagi pustakawan tersebut. Terampil dalam menjalankan tugas sebagai pustakawan, pustakawan yang terampil dalam menjalankan tugasnya diartikan memiliki pengetahuan yang luas, bersunguh-sunguh dalam bekerja, dan mengetahui jenis-jenis bahan koleksi pustaka di perpustakaan tersebut. Apabila pustakawan sudah memiliki tiga kemampuan tersebut, pustakawan dapat ditempatkan dilayanan referensi. Dalam melakukan peningkatan kinerja layanan manajer pustakawan atau pustakawan senior,harus melakukan evaluasi kinerja dari setiap barwahanya. Dilakukanya evaluasi dari hasil kinerja pustakawan berguna untuk memperbaiki kinerja yang kurang dari setiap pustakawan. Pustakawan diberikan pelatihan guna untuk mempertahankan dan memperbaiki kinerja pustakawan dalam layanan. Selain diberikan pelatihan, adanya pergantian pustakawan yang menjabat dalam perpustakaan tersebut yang bertujuan memberikan kesempatan terhadap pustakawan lainnya. Melakukan pergantian petugas pustakawan, merupakan salah satu cara untuk meningkatkan kualitas layanan.
Peningkatan kualitas pelayanan di perpustakaan bertujuan membuat pelayanan prima di perpustakaan. Pelayanan prima merupakan terjemahan dari excellent service artinya pelayanan terbaik. Pelayanan prima adalah upaya maksimal yang diberikan oleh petugas layanan dari suatu organisasi/lembaga jasa pelayanan untuk memenuhi harapan dan kebutuhan pelanggan sehingga tercapai suatu kepuasan (Nababan, n.d.). Dapat diartikan bahwa pelayanan prima berorientasi pada kepuasan pengguna layanan. Artinya pustakawan yang melakukan pelayanan sudah memenuhi syarat-syarat supaya menjadikan layanan tersebut menjadi pelayanan prima di perpustakaan. Inti dari peningkatan kualitas layanan di perpustakaan bertujuan untuk memberikan bantuan kepada pengguna perpustakaan dalam hal mencari informasi.

Masa pandemi covid-19 ini membuat masyarakat untuk melakukan social distancing dan physical distancing yang mengakibatkan masyarakat harus berada di rumah terus-menerus dan dilarang berdekatan satu sama lain. Sehingga masyarakat khususnya pekerja dan mahasiswa mau tidak mau harus melakukan kegiatan melalui online atau Work from Home (WfH). Petugas perpustakaan atau pustakawan memiliki tugasnya masing-masing dalam hal pelayanan tidak terkecuali layanan pengembangan koleksi. Pengembangan koleksi merupakan sebuah proses mengidentifikasi kekuatan dan kelemahan koleksi perpustakaan dalam memenuhi kebutuhan pengguna serta berupaya mengatasi kelemahan koleksi tersebut (Laksmi, 2013). Pengembangan koleksi ini memiliki peran yang penting dikarenakan dengan adanya layanan ini kita bisa 
mendapatkan informasi yang kita cari. Apalagi dimasa pandemi ini perpustakaan konvesional tutup berubah menjadi perpustakaan digital, yang dimana koleksikoleksi pustakanya tidak sebanyak perpustakaan konvesional. Pengembangan koleksi pun setiap jenis perpustakaanya pun berbeda-beda tergantung jenis perpustakaannya. Kali ini saya menggunakan pengembangan koleksi di perpustakaan perguruan tinggi. Perpustakaan perguruan tinggi merupakan perpustakaan yang membangun, memelihara, dan menyusun koleksi pustaka untuk memenuhi kebutuhan informasi dari mahasiswa dan staf akademik dalam melaksanakan kegiatan belajar mengajar, penelitian, dan pengabdian masyarakat atau yang disebut sebagai tridarma perguruan tinggi. Perpustakaan perguruan tinggi merupakan perpustakaan yang terdapat di perguruan tinggi, yang tugas utamanya merupakan membantu perugruan tinggi sesuai tridama.

Petugas dalam melakukan pengembangan koleksi memilik enam tahapan yang berfugnsi untuk mendapatkan koleksi yang terbaik seperti tahapan pertama : Analisis kebutuhan masyarakat dalam mencari koleksi pustaka atau informasi. Tahapan pertama analisis ini cukup penting supaya kita mengetahui yang dibutuhkan masyarakat, menjadikan perpustakaan memiliki koleksi-koleksi pustaka yang dibutuhkan dan memilah koleksi pustaka yang sudah tidak diminati di masyarakat. Dengan diadakanya analisis kebutuhan membuat pustakawan memiliki, karakteristik profesionalisme dimana pustakawan harus memiliki ilmu pengetahuan, keterampilan dan keahlian terhadap bidang sains informasi dan perpustakaan. Selain memiliki karakteristik profesionalisme, dengan adanya analisis kebutuhan membuat sumber daya manusia di lingkungan perpustakaan memadai dikarenakan untuk melakukanya harus memiliki basic ilmu informasi dan perpustakaan. Apalagi perkembangan teknologi informasi yang begitu pesat, membuat pustakawan harus berjuang lebih lebih exstra lagi dalam hal pelayanan. Kebutuhan terhadap koleksi pun semakin beragam, dikarenakan mudahnya mendapatkan koleksi. Selain perkembangan teknologi informasi, saat ini kita sedang dilanda pandemi virus covid-19 di seluruh dunia.

Biasanya kita analisis kebutuhan masyarakat, sekarang ditambah lagi masa pandemi covid-19. Pustakawan dituntut untuk memberikan informasi yang valid dan mudah dipahami oleh masyarakat luas tentang covid-19 ini sebagai ahli informasi. Masyarakat sekarang pun harus terbiasa dengan kehidupan baru dimana, kita menerapkan social distancing, workfromhome dalam melakukan pekerjaan. Perpustakaan pun mengalami work from home dimana pustakawan dahulu untuk kerja datang langsung, sekarang melakukanya dirumah banyak petugas perpustakaan sudah usia lanjut kesulitan menggunakan teknologi. Perkembangan koleksi selama masa pandemi covid-19 tetap harus berjalan seperti sedia kala, pustakawan dituntut tetap melakukan analisis terhadapa kebutuhan masyarakat. Perbedaanya yaitu pustakawan, melakukan analisis terhadap informasi covid-19 ini yang bertujuan untuk menfilter informasi yang tidak benar yang membuat masyarakat tambah kebingungan dan ketakutan.

Pandemi covid-19 membuat masyarakat berpikir keras, bagaimana cara 
bertahan hidup atau survive dengan melewati pandemi ini. Banyak usaha yang tutup, ada yang bertahan dengan mencari inovasi-inovasi baru tidak lupa perpustakaan pun terkena dampak covid19. Perpustakaan sebelum pandemi ini masyarakat bisa datang langsung untuk mencari informasi, adanya pandemi ini tidak bisa datang langsung. Inovasi perpustakaan untuk memberikan layanan disaat pandemi ini dengan adanya perpustakaan digital, walaupun tidak semua perpustakaan memiliki perpustakaan digital ini. Hadirnya perpustakaan digital ini memberikan cahaya baru terhadap masyarakat yang membutuhkan informasi, koleksi dan lainlain. Tidak lupa koleksi perpustakaanya pun yang dimana terdahulu masih berupa fisik sekarang sudah berubah menjadi digital. Pustakawan pun melakukan analisis, kebutuhan melalui data visitor online pengguna kebanyakan mencari koleksi apa di perpustakaan digital.

Perpustakaan digital ini harus membuat nyaman si pengguna seperti perpustakaan konvesional lainnya, dengan memberikan kemudahan akses dan pengoperasiannya. Perbaikan kualitas sistem yang dimaksud dapat dilakukan dengan cara membangun website yang well-designed. Misalnya tata letak rapi, tampilan visualnya menarik, isi informasinya beragam (Suharso, Arifiyana, \& Wasdiana, 2020). Sistem katalogisasi dengan menggunakan teknologi informasi yaitu Online Public Access Catalog (opac), dimana teknologi ini berfungsi untuk mengecek jenis, jumlah dan ketersediaan koleksi di perpustakaan. Selain inovasi perpustakaan digital terhadap user-experience dan userinterface perpustakaan melakukan inovasi terhadap pengembangan koleksi dimana perpustakaan melakukan kerja sama antar perpustakaan satu dengan yang lainya yang bernama Resource sharing. Dengan diadakanya Resource sharing diharapkan bisa membuat koleksinya bertambah. Kedua perpustakaan tersebut membuat perpustakaan digital yang berasal dari kedua koleksi tersebut untuk mengisi kekosongan koleksi.

Selain kerja sama dalam bidang koleksi perpustakaan, terdapat kerjasama dalam memanfaatkan dan membagi sumber daya perpustakaan. Sumber daya perpustakaan disini memberikan inovasi dan pelatihan ke perpustakaan lain dan perpustakaan lain memberikan hal yang serupa kepada kita. Kerja sama tersebut bertujuan untuk saling melengkapi antar perpustakaan. Adanya kerja sama itu bertujuan supaya perpustakaan memiliki koleksi-koleksi baru, inovasi baru dan mendapatkan latihan skill baru yang akan diterapkan di perpustakaan. Selain invoasi itu terdapat inovasi lain dimana dilakukan shif kerja atau membuka program internship atau magang untuk membuat perpustakaan semakin berkembangan dikarenakan adanya anak muda yang kaya akan ide kreatif dan invoasi masuk yang membuat perpustakaan semakin berwarna. Intership disini merupakan magang yang dimana suatu perpustakaan membuka lowongan tersebut bertujuan untuk mendapatkan suatu invosi baru dari intership ini. Sedangkan orang yang mengikuti intership mendapatkan pengalaman baru, teman baru yang berguna untuk di dunia kerja nanti. Pengalaman baru disini bisa berkembanganya suatu skill yang kita punya atau mendapatkan skill baru dalam intership. 


\section{KESIMPULAN}

Perkembangan zaman yang begitu pesat tidak lupa informasi pun ikut berkembang pesat, dimana dahulu untuk mendapatkan informasi medianya pun masih terbatas hanya koran, tv, radio, dan lain-lain. Sekarang informasi melimpah ruah dan tidak terbendung arus informasinya, oleh karena itu masyarakat sekarang harus bisa membedakan informasinya yang valid dan baik buat kita dan mana yang tidak baik buat kita. Apalagi saat ini dunia sedang terjadi pandemic Covid-19 dimana penyakit ini terjadi oleh virus bernama SARS-CoV-2. Akibat virus SARS-CoV-2 ini kita diwajibkan untuk bekerja, belajar dan melakukan aktivitas dirumah yang dimana sebelumnya kita melakukannya di luar rumah. Semuanya terkena dampak oleh pandemi covid-19 ini tidak terkecuali lembaga informasi yaitu perpustakaan. Di masa seperti saat ini, para masyarakat akan memfokuskan dirinya pada media berita melalui televisi, media sosial maupun media online lainnya. Masyarakat juga akan menggunakan waktunya untuk berselancar informasi di internet dan media komunikasi seperti Line, WhatsApp, Telegram, Facebook, Twitter, dan Instagram untuk memperoleh informasi terbaru/ up-to-date terkait dengan Covid19 (Suharso, Arifiyana, \& Wasdiana, 2020).

Lembaga informasi yaitu perpustakaan berasal dari kata berasal dari bahasa latin yaitu libre atau liber yang artinya buku. Perpustakaan dalam bahasa belanda disebut bibliotheca,Jermandisebut bibliothek,Perancis disebut bibliotheque.Spanyol disebut bibliotheca dan Portugis disebut bibliotheca. Semua istilah itu berasal dari yunani yang artinya buku. Perpustakaan terbagi menjadi empat jenis yaitu perpustakaan umum, perpustakaan sekolah, perpustakaan perguruan tinggi dan perpustakaan khusus. Keempat jenis perpustakaan memiliki empat fungsi dasar perpustakaan yaitu fungsi informatif, edukatif, kultural dan rekreasi. Perpustakaan memiliki dua layanan yaitu layanan referensi dan layanan sirkulasi. Layanan Referensi ini merupakan layanan yang sangat dibutuhkan oleh suatu lembaga informasi yaitu perpustakaan. Layanan tersebut merupakan tolak ukur bagus tidaknya suatu perpustakaan dalam menangani pencarian informasi. Layanan referensi berasal dari kata reference dimana dalam Bahasa Inggris to refer yang artinya menunjuk. Sedangkan dalam Kamus Besar Bahasa Indoesia adalah sumber, acuan, rujukan atau petunjuk. Sedangkan layanan sirkulasi merupakan suatau kegiatan layanan peminjaman dan pengembalian koleksi di perpustakaan yang sudah terprogram didalam perpustakaan. Kegiatan layanan sirkulasi hampir mirip dengan layanan referensi seperti menyediakan bahan pustaka, mengadakan pengawasan koleksi akan tetapi layanan sirkulasi tidak mencatat pertanyaanpertanyaan yang diajukan oleh pengguna perpustakaan Dalam perpustakaan terdapat petugas perpustakaan yang bernama pustakawan. Pustawan bekerja semua hal seperti hal pengadaan,penggunaan serta pendayagunaan buku.

Perkembangan zaman membuat teknologi informasi masuk kedalam perpustakaan, oleh karena itu perpustakaan konvesional berubah menjadi perpustakaan digital. Perpustakaan digital atau library digital merupakan perpustakaan yang menggunakan teknologi terbaru dalam pelayananya, 
perpustakaan digital sudah dimiliki di seluruh dunia termasuk Indonesia. IFLA (The International Federation of Library Associations and Institutions) (2018) mendefinisikan perpustakaan digital sebagai berikut: "a digital library is an online collection of digital objects, of assured quality, that are created or collected and managed according to internationally accepted principles for collection development and made accessible in a coherent and sustainable manner, supported by services necessary to allow users to retrieve and exploit the resources." yang mengandung arti bahwa perpustakaan digital merupakan perpustakaan yang memiliki koleksi online yang berisi objek digital dengan yang berkualitas, dikembangkan dan dikelola sesuai dengan prinsip secara internasional. Selain itu, koleksi yang ada dapat diakses secara berkelanjutan atau dibuka secara terus-menerus yang didukung oleh layanan-layanan yang diperlukan oleh pengguna ketika menggunakan/ membutuhkan sumber informasi. Perpustakaan digital ini pertama kali oleh Perpustakana Institut Teknologi Bandung Bandung pada tahun 1980an dan sekarang hampir semua perpustakaan memiliki perpustakaan digital.

Menggunakan perpustakaan digital banyak sekali manfaat yang bisa didapatkan oleh pengguna, diantaranya seperti tidak membutuhkan ruangan untuk menyimpan koleksi pustaka, bisa diakses kapan saja dimana saja dan jam berapa saja. Contoh teknologi perpustakaan digital yaitu adanya katalog online atau online public access catalogue (opac) bertujuan untuk mencari suatu pustaka dalam perpustakaan tanpa harus mendatangi raknya satu persatu. Perpustakan digital tidak memerlukan banyak biaya. Mendigitalkan koleksi perpustakaan lebih murah dibandingkan dengan membeli buku. Mencegah duplikasi dan plagiat. Perpustakaan digital lebih "aman", sehingga tidak akan mudah untuh diplagiat. Bila penyimpanan koleksi perpustakaan menggunakan format PDF, koleksi perpustakaan hanya bisa dibaca oleh pengguna, tanpa bisa mengeditnya. Publikasi karya secara global. Dengan adanya perpustakaan digital, karya-karya dapat dipublikasikan secara global ke seluruh dunia dengan bantuan internet. Seiring perkembangan jaman jenis koleksi perpustakaan pun mengalami perubahan, yang semula hanya berbentuk fisik sekarang memiliki koleksi digital. Sumber daya elektronik ini terdiri dari delapan jenis sumber yaitu jurnal elektronik, buku elektronik (e-books), pangkalan data naskah lengkap (aggregated databases), pangkalan data indeks dan abstrak, pangkalan data referensi, pangakalan data statistik dan angka, gambar elektronik, sumber daya audio / visual elektronik.

Untuk mengetahui jenis-jenis koleksi yang dibutuhkan oleh masyarakat luas, diperlukan analisis masyarakat atau diperpustakaan terdapat layanan pengembangan koleksi. Pengembangan koleksi (collection development) sebuah proses mengidentifikasi kekuatan dan kelemahan koleksi perpustakaan dalam memenuhi kebutuhan pengguna serta berupaya mengatasi kelemahan tersebut (Laksmi, 2013). Diadakanya pengembangan koleksi bertujuan supaya koleksi-koleksi yang diserahkan kepada pengguna atau masyarakat tepat dan dibutuhkan oleh masyarakat. Petugas perpustakaan melakukan pengembangan koleksi dengan enam tahapan proses pengembangan koleksi yaitu analisis kebuhutan masyarkat, kebijakan 
pengembangan koleksi, pemilihan koleksi atau bahan pustaka, tahap pengadaan koleksi, tahap penyiangan koleksi, terakhir tahap evaluasi. Pandemi covid-19 memberikan dampak yang begitu besar kepada semua elemen, termasuk perpustakaan.

Perpustakaan itu sendiri melakukan inovasi terhadap perpustakaan itu sendiri dan sumber daya manusianya. Inovasi terhadap peningakatan sumbe daya manusia dalam perpustakaan dilakukanya evaluasi dari hasil kinerja pustakawan berguna untuk memperbaiki kinerja yang kurang dari setiap pustakawan. Pustakawan diberikan pelatihan guna untuk mempertahankan dan memperbaiki kinerja pustakawan dalam layanan. Selain diberikan pelatihan, adanya pergantian pustakawan yang menjabat dalam perpustakaan tersebut yang bertujuan memberikan kesempatan terhadap pustakawan lainnya. Melakukan pergantian petugas pustakawan, merupakan salah satu cara untuk meningkatkan kualitas layanan. Sedangkan untuk inovasi terhadap perpustakaan dengan memberikan layanan disaat pandemi ini dengan adanya perpustakaan digital, walaupun tidak semua perpustakaan memiliki perpustakaan digital ini. Hadirnya perpustakaan digital ini memberikan cahaya baru terhadap masyarakat yang membutuhkan informasi, koleksi dan lainlain. Tidak lupa koleksi perpustakaanya pun yang dimana terdahulu masih berupa fisik sekarang sudah berubah menjadi digital. Pustakawan pun melakukan analisis, kebutuhan melalui data visitor online pengguna kebanyakan mencari koleksi apa di perpustakaan digital. Sistem katalogisasi dengan menggunakan teknologi informasi yaitu Online Public
Access Catalog (opac), dimana teknologi ini berfungsi untuk mengecek jenis, jumlah dan ketersediaan koleksi di perpustakaan. Selain inovasi perpustakaan digital terhadap user-experience dan userinterface perpustakaan melakukan inovasi terhadap pengembangan koleksi dimana perpustakaan melakukan kerja sama antar perpustakaan satu dengan yang lainya yang bernama Resource sharing. Dengan diadakanya Resource sharing diharapkan bisa membuat koleksinya bertambah. Kedua perpustakaan tersebut membuat perpustakaan digital yang berasal dari kedua koleksi tersebut untuk mengisi kekosongan koleksi.

\section{DAFTAR PUSTAKA}

Covid-, P., Suharso, P., Arifiyana, I. P., \& Wasdiana, D. (2020). Available Online at : http://ejournal.undip.ac.id/index.p hp/anuva Layanan Perpustakaan Perguruan Tinggi dalam Menghadapi Abstrak. 4(2), 271286.

Ibrahim, A., \& Afrina, M. (2011). Pengembangan Model Perpustakaan Berbasis Teknolig Informasi Untuk Meningkatkan Kinerja Layanan Perpustakaan dan mewujudkan Perpustakaan Ideal Berbasis digital. Prosiding Konferensi Nasional Teknologi Informasi Dan Aplikasinya (KNTIA2011), C87--C94. Retrieved from http://eprints.unsri.ac.id/5590/

Khadijah, C. (2019). Transformasi perpustakaan untuk generasi millenial menuju revolusi industri 4.0. IQRA : Jurnal Ilmu Perpustakaan Dan Informasi (e- 


\section{Info Bibliotheca}

Jurnal Perpustakaan dan IImu Informasi

Published by Program Studi Perpustakaan dan Ilmu Informasi FBS Universitas Negeri Padang, Indonesia

Journal), 12(2), 59.

https://doi.org/10.30829/iqra.v12i2 .3983

Kosasih, A. (2009). Faktor-Faktor yang Mempengaruhi Kualitas Layanan Prima di Perpustakaan Oleh : Aa Kosasih, S. Sos. / Pustakawan Pertama. Ilmu Perpustakaan, 110. Retrieved from https://scholar.google.co.id/scholar ?q=related:FbVNqqhgn6YJ:schola r.google.com $/ \& h l=i d \&$ as_sdt $=0,5$

Laksmi. (2013). Pengembangan Koleksi. 1.5 .

Listiani, W. (2008). Mengukur Kualitas Layanan Referensi. /Jurnal/Fihris/Fihris Vol. II No. 1 Januari-Juni 2007/, 1-22.

Retrieved from http://digilib.uinsuka.ac.id/349/1/MENGUKUR KUALITAS LAYANAN REFERENSI.pdf

Nugrahini, N. (2014). Layanan Referensi dan Promosi Koleksi Referensi. ABA Journal, 2(2), 129-138. https://doi.org/10.1017/CBO97811 07415324.004

Pendit, P. L. (2008). Perpustakaan Digital Perguruan Tinggi : Tantangan Peningkatan Kualitas Jasa. 7. Retrieved from http://eprints.undip.ac.id/5367/2/m akalah_pak_putu.pdf

Saleh, A. R. (2014). Pengertian, Manfaat, dan Kelebihan Perpustakaan Digital. 1-43.

Winarko, B. (2009). Perpustakaan Digital Di Indonesia Dan Fitur-Fitur Yang Tersedia. Jurnal Perpustakaan
Pertanian, 18(2), 45-49. Retrieved from

http://pustaka.litbang.pertanian.go. id/publikasi/pp182093.pdf 